\title{
Relationship between perceived self-efficacy and teaching practice performance among pre-service basic science teachers in colleges of education, Delta State, Nigeria
}

\author{
Stella Ejovwoke Ewesor \\ Department of Integrated Science \\ Delta State College of Education Mosogar, \\ Delta State. Nigeria \\ E-mail: ewesorstella@gmail.com \\ Cell: +2348100691688 \\ Andrew O. Urevbu, Prof. \\ Department of Curriculum and Instructional Technology \\ Faculty of Education \\ University of Benin, Benin City, Nigeria \\ Cell: +2348037243134
}

\begin{abstract}
The study examined the relationship between perceived self-efficacy of pre-service basic science teachers and teaching practice performance in colleges of education in Delta State, Nigeria. One hundred and twelve (112) pre-service basic science teachers were selected from two colleges of education in Delta State. Forty-six (46) from College of Education 1 (COEI) while sixty-six (66) from College of Education II (COEII). The study tested three hypotheses derived from the three research questions. The independent variable was perceived selfefficacy of the pre-service basic science teachers, the dependant variable was teaching practice while the moderating variables were two colleges of education of the pre-service science teachers. The instruments used were "Teaching Practice Assessment Score Instrument (TPASI)" and the "Pre-Service Science Teachers Perceived Self Efficacy (PSTPSE)" with thirty (30) questions. Person correlation was used to test the hypotheses. The results showed that the three null hypotheses were accepted. The hypothesis one is accepted because there was no significant relationship found to exist between the pre-service basic science teachers perceived self-efficacy and their teaching practice assessment scores. Also, no significant difference was found between COEI and COEII pre-service basic science teachers' perceived self-efficacy scores and their performance in teaching practice. Finally, for all the pre-service basic science teachers irrespective of their subject combination, there was no relationship between their perceived self-efficacy and the teaching practice assessment. Consequently, it was recommended that there should be a reform in pre-service teacher education programmes in all our teachers training institutions; it can help to develop and improve teacher education programmes and pre-service teaching practice; this reform should aim at strengthening both content and pedagogical knowledge of pre-service teachers.
\end{abstract}

Keywords: Perceived self-efficacy, Teaching practice, Pre-service teachers, Basic science, Colleges of education, Delta State, Nigeria

\section{Introduction}

Teacher education plays an important role in preparing pre-service teachers to teach science because teachers are the key and crucial factor in achieving success of any educational system in a nation Hecter, (2011). Moreso, the teacher can significantly influence students' achievement in order for the students to be able to play their roles in the society to achieve the national set objectives. In order for these to happen, there should be development for appropriate teaching skills that will require the provision of adequate opportunities to "practice teaching".

Bandura (1993) defined perceived self-efficacy as peoples' beliefs about their capabilities to produce effects or designated levels of performance that exercise influence over events that affect their lives. Bandura also said that perceived self-efficacy influence all aspect of behaviour that includes acquisition of new behaviour and inhibition of 'existing behaviour. It also affects people's choice 
Stella Ejovwoke Ewesor and Andrew O. Urevbu: Relationship between perceived selfefficacy and teaching practice performance among pre-service basic science teachers in colleges of education, Delta State, Nigeria

of behavioural setting, the amount of effort they will expand on a task and the length of time that will persist in the face of obstacles. These beliefs are diverse into four major processes. These include cognitive; motivational; affective and selection processes.

Perceived self-efficacy affects every phase of personal life and people's judgment of their personal efficacy. And, mood affects people's view because positive mood enhances perceived selfefficacy while negative or sad mood diminishes it. There are three different levels at which perceived self- efficacy operates as an important contributor to academic development. Students' belief is their efficacy to regulate their own learning and to master academic activities, determine their aspirations, level of motivation and academic accomplishment.

Perceived self-efficacy develops based on the appraisal of pre-service teachers of their experiences and they build self-efficacy in teaching basic science. It is important for pre-service teachers to have experiences in which they feel successful while teaching students during their science classes. This study will investigate the relationship between perceived self-efficacy and teaching practice performance among pre-service basic science teachers in colleges of education, Delta State, Nigeria.

\section{Statement of problem}

The study of perceived self-efficacy of learners has in recent time evolved in diverse spheres of human endeavour and knowledge acquisition in spite of some useful suggestive educational probing so far reported/ it is still very evident that there might be some nuts left to be cracked due to different factors that some researchers reported as influences the perceived self-efficacy of teachers in several learning fields including sciences. There is no doubt that most basic science teachers have some challenges in teaching some topics in basic science curriculum. This is due to the fact that both pre-service and in-service teachers perceived some difficulties in the subject as they are inadequately prepared to teach it in primary and junior secondary school. Evidences also revealed that both preservice and in-service teachers lack the confidence to teach Basic Science and their self-efficacy regarding basic science teaching at the primary and junior secondary school levels is very low (Schoeneberger \& Russell, 1986; Ecochs \& Riggs, 1990; Mulholland \& Wallace, 2000; Appleton .2003; Mulholland, Dorman \& Odgers, 2004). Consequently, there is need for additional research, particularly in Nigerian colleges of education setting where there is high decline in students enrolment and a greater need on trying to figure out how incubationery teachers develop or rather are made through their learning processes as well as the teaching practice programme.

Several studies such as Brand and Wilkins (2007) in Aurah and McConnell (2014) have shown that most junior school science teachers have negative belief about science which has resulted in science anxiety, poor attitudes toward science and unwillingness to spend adequate time for teaching science. This seems to make many pre-service science teachers show dislike, fear and failure to study science and scientific concepts wholly, because there are no known studies that have examined perceived self-efficacy regarding the ability to teach Basic science in primary and junior secondary schools nor the relationship between the teaching practice programme and pre-service teachers' self-efficacy in teaching the subject has provided the needed force for this present study. The researcher investigated the relationship between perceived self-efficacy and teaching practice performance among pre-service 
Stella Ejovwoke Ewesor and Andrew O. Urevbu: Relationship between perceived selfefficacy and teaching practice performance among pre-service basic science teachers in colleges of education, Delta State, Nigeria

basic science teachers in colleges of education in Delta State, Nigeria.

\section{Research questions}

The following questions are answered in this study:

Is there any relationship between the perceived self-efficacy of pre-service Basic Science Teachers and their performance in teaching practice?

1. Is there any relationship between College of Education 1 and College of Education II pre-service basic science teachers' perceived selfefficacy and their performance in teaching practice?

2. Is there any relationship between subject combinations of pre-service basic science teachers' perceived self-efficacy and their performance in teaching practice?

\section{Hypotheses}

The following hypotheses are tested in the study:

1. There is no significant relationship between the perceived self-efficacy of pre-service basic science teachers and their performance in teaching practice.

2. There is no significant relationship between College of Education 1 and College of Education II perceived self-efficacy and their performance in teaching practice.

3. There is no significant relationship between subject combinations of pre-service basic science teachers' perceived self-efficacy and their performances in teaching practice.

\section{Methods}

The research design adopted for this study is correlation design which is a type of experimental research in which the researcher measure two or more vehicles and assessment scores to obtain data from the respondent that is, pre-service basic science teachers. The scores explain

Teaching Practice Assessment Instrument (TPAI) used by the lecturers to access the pre-service science teachers during teaching practice and the Pre-Service Science Teachers Self-Efficacy (PSTPSE). Bandura's instrument of Teachers SelfEfficacy was given to the pre-service science teachers to elicit information from them for the study. Independent variable is the perceived self-efficacy of the preservice basic science teachers, dependent variable is the teaching practice while moderating variables is the colleges of the pre-service science teachers.

The population of the study comprised of two hundred and fifteen (215) year three (3) pre-service basic science teachers of the Departments of Physics, Chemistry, Biology, Computer Science, Mathematics, Integrated Science in two colleges of education in Delta State. Ninety (90) pre- service basic science teachers from College of Education I and one hundred and twenty-five (125) preservice basic science teachers from College of Education II.

A total of 112 pre-service science teachers formed the sample for this study while the population for the study comprises of 215 pre-service science teachers. The sample for this study consisted of forty-six (46) and sixty-six (66) Pre-Service Science Teachers forming fifty percent $(50 \%)$ of ninety (90) students from College of Education 1 and one hundred and twenty-five (125) students from College of education II respectively. The forty-six (46) and sixty-six (66) preservice science teachers sampled from each of the colleges of education were got by finding $50 \%$ of each category based on subject combination of students in the two colleges of education and figures existing in decimal forms will be rounded off because there cannot be 0.5 percent for equitable representation of each category as shown in the Tables 6 and 7 .

The instruments used for this study are grouped into two (2) as shown as followa: 
Stella Ejovwoke Ewesor and Andrew O. Urevbu: Relationship between perceived selfefficacy and teaching practice performance among pre-service basic science teachers in colleges of education, Delta State, Nigeria

1. Bandura's instrument of Teacher Self-Efficacy Scale (BITSES): The research instrument for the study is the questionnaire for pre-service teachers perceived self-efficacy which has two divisions, The first division is structured to give background information about each pre-service basic science teachers used for the study while the second division contain the questions that are meant to determine the students perceived self-efficacy. It contains 30 items on four points Likert scale.

2.Teaching Practice Assessment Score Form (TPASF): The research instrument used for the Study is the teaching practice assessment form which has four (4) divisions. the first division is structured to elicit individual preservice basic science teachers data. and, the second division is classified into six sub-divisions specific score for each of them, the third division is the rounding scores of the pre-service basic science teachers while the fourth division is the remark of the supervisor (lecturer), signature with date of supervision.

The instrument was content validated by researcher's supervisor who made suggestions and corrections and two research experts in the Department of Curriculum and Instructional Technology, University of Benin and one from Delta State College of Education, Mosogar. All corrections and comments were effected asking the researcher to adopt Bandura's instrument of Teacher Self- Efficacy Scale. A four point Likert scale was used and participants were asked to gauge their self- efficacy by indicating the extent to which they agreed with each statement using (1) NT (Nothing) (2) VL (Very Little) (3) SI (Some Influence) (4) AGD (A Great Deal).

In order to ensure the reliability of the instrument, a pilot study was conducted with twenty (20) pre-service science teachers of the Delta State College of Education, Mosogar that were not part of the sample. Reliability co-efficient of 0.71 was obtained using Cronbach Alpha method that was looked adequate for the study. The data collected were the Bandura's instrument of Teacher SelfEfficacy Scale which comprised of thirty (30) questions given to the pre-service basic science teachers of the two colleges of education in Delta State to tick their responses and they were also collected immediately to avoid alteration. Also, the teaching practice assessment instrument of the pre-service basic science teachers of the various subject combinations from the two colleges of education, in Delta State.

Forty-six (46) questionnaires were administered to pre-service science teachers of College I while sixty-six (66) to College II. The total of one hundred and twelve (1 12) Pre-Service Basic Science Teacher Bandura's instrument of Teacher Self-Efficacy Scale and Teaching Practice Assessment Score were collected for analysis. Research questions were answered using mean (Y) and standard deviation (SD) at 0.05 level of significance while the hypotheses were tested by using Pearson Bivariate Coorrelation to determine relationship and result were further stated.

\section{Results}

Research question one: Is there any relationship between the perceived selfefficacy of pre-service basic science teachers and their performance in teaching practice? 
Stella Ejovwoke Ewesor and Andrew O. Urevbu: Relationship between perceived selfefficacy and teaching practice performance among pre-service basic science teachers in colleges of education, Delta State, Nigeria

Table l: Descriptive statistics for perceived self-efficacy scores and teaching practice assessment scores of the pre-service basic science teachers

\begin{tabular}{lccccc}
\hline $\begin{array}{l}\text { Variables } \\
\text { difference }\end{array}$ & $\mathbf{N}$ & $\mathbf{\Sigma}$ & $\overline{\boldsymbol{X}}$ & $\begin{array}{l}\text { Standard } \\
\text { deviation }\end{array}$ & $\begin{array}{c}\text { Mean } \\
\text { differerence }\end{array}$ \\
\hline $\begin{array}{l}\text { Perceived self - efficacy } \\
\text { score PSES }\end{array}$ & 112 & 8456 & 75.77 & 18.79 & \\
$\begin{array}{l}\text { Teaching practice } \\
\text { assessment score (TPAS) }\end{array}$ & & & & & 13.24 \\
& 7003 & 62.53 & 6.43 & \\
\hline
\end{tabular}

Where PSES = Perceived Self Efficacy Scores

TPAS $=$ Teaching Practice Assessment Scores

Table 1 shows that the means and standard deviation of the PSES and TPAS groups are 75.77 and $18.79 ; 62.53$ and 6.43 respectively, and mean differences between PSES and TPAS groups is 13.24, Therefore, there is difference between the means of the two groups.

Research question two: Is there any relationship between College of Education I and College of Education II pre-service basic science teachers' perceived selfefficacy and their performance in teaching practice?

Table 2: - Descriptive statistics for PSES and TPAS of COE 1 and

COE 2 groups

\begin{tabular}{clcccc}
\hline $\mathrm{N}$ & Variables & $\boldsymbol{\Sigma} \mathrm{x}$ & $\bar{X}$ & sd & Mean differences \\
\hline & PSES & 3867 & 83.63 & 18.99 & \\
COE 1 46 & TPAS & 2982 & 64.83 & 5.75 & and \\
& & & & & 3.91 \\
COE 2 66 & SES & 4639 & 70.27 & 16.90 & \\
& TPAS & 4021 & 60.92 & 6.41 & \\
\hline
\end{tabular}

Table 2 shows the differences in the means and standard deviation of perceived selfefficacy scores and teaching practice assessment scores of all the students in the COE1 group as well as COE2 groups. The mean differences between COEI and COE2 PSES is 13.36 while COE1 and
COE2 TPAS is 3.91 .

Research question three: Is there any relationship between subject combinations of pre-service basic science teachers perceived self-efficacy and their performance in teaching practice? 
Stella Ejovwoke Ewesor and Andrew O. Urevbu: Relationship between perceived selfefficacy and teaching practice performance among pre-service basic science teachers in colleges of education, Delta State, Nigeria

Table 3 - Descriptions for COE1 and COE2 PSES and TPAS

\begin{tabular}{ccccc}
\hline Samples & $\mathbf{N}$ & $\overline{\boldsymbol{X}}$ & Sd & $\begin{array}{c}\text { Mean } \\
\text { difference }\end{array}$ \\
\hline Physics & 12 & 63.08 & 8.11 & -8.254 \\
PSES & & 64.83 & 4.03 & \\
TPAS & 62 & 77.68 & 20.14 & 15.50 \\
Chemistry & 62.18 & 6.99 & \\
PSES & & 62.15 & 20.71 & 19.17 \\
TPAS & 55 & 80.15 & 6.86 & \\
Biology & & 60.98 & & \\
PSES & & & 12.69 & 1.84 \\
TPAS & 12 & 67.17 & 4.92 & \\
Mathematics & & 65.33 & & \\
PSES & & & & \\
TPAS & 15 & 66.67 & 15.46 & 1.51 \\
Integrated Science & 15 & 65.16 & 7.03 & \\
PSES & & & & \\
TPAS & & & & \\
\hline
\end{tabular}

Table 3 shows that there are differences in the mean and standard deviation of all the sample groups. The differences between Physics group is -8.25 ; Chemistry group is 15.50, Biology group is 19.17 ,

Mathematics group is 1.84 and Integrated Science group is 1.51. Result of mean difference also shows that Integrated Science group had the lowest (1.51), while
Biology' group had the highest (19.17). The hypotheses were tested using Pearson Bivariate correlation to determine relationship.

Hypothesis one: There is no significant relationship between perceived selfefficacy of pre- service teachers and their performance in teaching practice

Table 4: Summary table of pearson correlation statistics on PSES/TPA

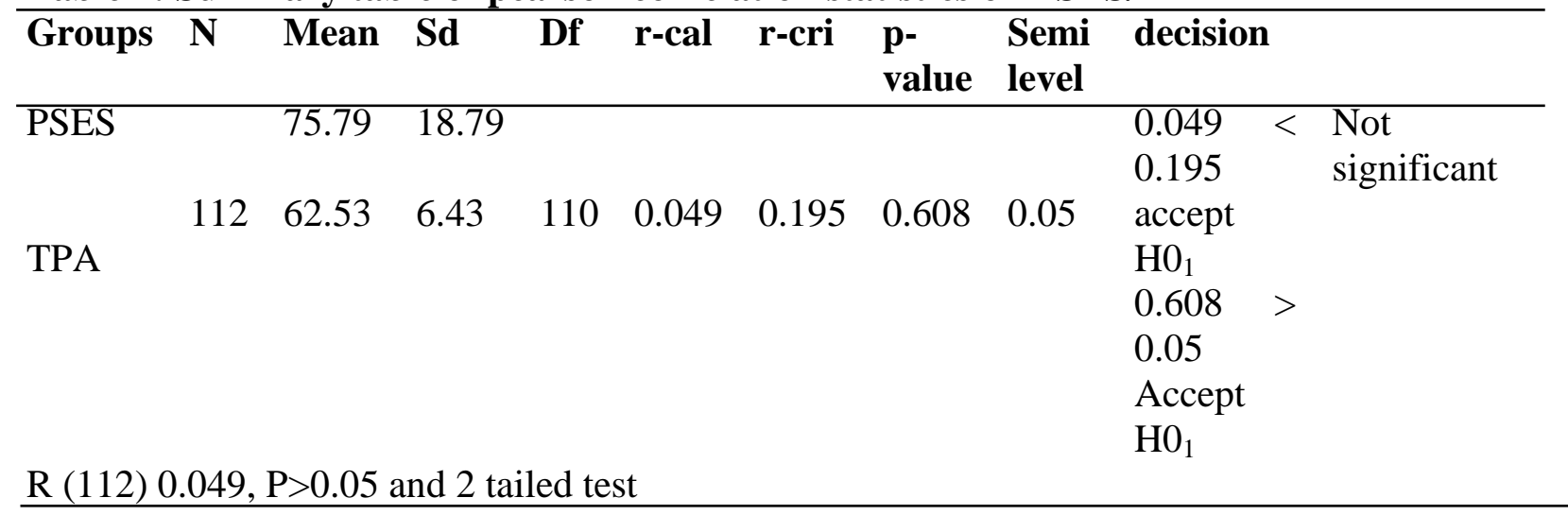

Table 4 shows that there is a positive correlation 0.049. This means positive correlation exists between the students' perceived self-efficacy scores and their teaching practice assessment scores. As one group increases or decreases, the other also increases or decreases. The $r$ value of
0.049 is very low and closer to (0) zero than to 1 . This shows the relationship has very low strength. This means no significant relationship is found to exist between students perceived self-efficacy and their teaching practice assessment. Also, the $\mathrm{P}$ value of 0.608 is greater than

Tropical Journal of Education, Volume 2, Numbers 1/2, 2020 
Stella Ejovwoke Ewesor and Andrew O. Urevbu: Relationship between perceived selfefficacy and teaching practice performance among pre-service basic science teachers in colleges of education, Delta State, Nigeria

the significant level or" 0.05 which also means no significant relationship. Therefore, hypothesis one is accepted.

Hypothesis two: There is no significant relationship between COE1 and COE2 of perceived self- efficacy and their performance in teaching practice.

Table 5: Summary table of paired samples Bivariate correlation of PSES and TPA of students in COE1 and COE II

\begin{tabular}{|c|c|c|c|}
\hline Samples & $\overline{\mathbf{V}}$ & $\begin{array}{l}\text { Correlations } \\
\text { r-value }\end{array}$ & r-cri \\
\hline
\end{tabular}

\begin{tabular}{llllll} 
COE1 PSES - COE1 TPAS & 46 & -0.120 & 0.288 & 0.428 & NS \\
COE2 PSES - COE2 TPAS & 66 & -0.024 & 0.232 & 0.850 & NS \\
COE1 PSES - COE2 TPAS & 46 & -0.146 & 0.288 & 0.332 & NS \\
COE1 PSES - COE2 PSES & 46 & -0.194 & 0.288 & 0.196 & NS \\
COE1 TPA - COE2 TPAS & 46 & -0.154 & 0.288 & 0.307 & NS \\
COE1 PSES - COE2 TPAS & 46 & 0.190 & 0.288 & 0.205 & NS \\
\hline
\end{tabular}

2 - tailed test @0.05 level of significant

Samples 1 - 6 r cal < r-cri (NS)

The result in Table 5 clearly shows there is no significant difference between COE1 and COE2 perceived self-efficacy scores and their teaching practice performances in all the samples with $\mathrm{P}>0.05$. We therefore retain Hypothesis two. Also with $r$ calculated values lesser than $r$ critical values in all the cases is seen in table 5, the null hypothesis two is retained or accepted.

The negative values of $\mathrm{r}(-0.120$, 0.024 , etc) also shows that the correlation between PSES and TPA scores are negative meaning as one variable increases, the other decreases. Note that the r-value in the six sample COE1 PSES and COE2 TPAS is positive (O.19O) but is still not significant. Analysis of $\mathrm{HO} 2$ from all the results shows that $\mathrm{HO} 2$ is retained therefore no significant relationships is found between COE1 and COE2 preservice basic science teachers perceived self - efficacy scores and their performance in teaching practice.
Hypothesis three: There is no significant relationship between subject combination of pre-service basic science teachers perceived self-efficacy and their performance in teaching practice.

Analysis of data in Table 6 shows that the correlation values for all the subjects combination in the relationship between pre-service science teachers perceived self-efficacy and assessment are different. The physics group had the highest p-value of 0.675 while the Biology group had the lowest P-value of 0.189, however, No significant difference occurred within the subject combinations. This means Hypothesis three is accepted for all the subject combination. The preservice basic science teachers irrespective of their subject combinations, there was no relationship between their perceived self efficacy and their teaching practice assessment. 
Stella Ejovwoke Ewesor and Andrew O. Urevbu: Relationship between perceived selfefficacy and teaching practice performance among pre-service basic science teachers in colleges of education, Delta State, Nigeria

Table 6: Pearson paired sample bivariate correlation analysis for different subject groups perceived self-efficacy and teaching practice assessment

\begin{tabular}{llllllll}
\hline \multicolumn{2}{l}{ Samples } & N & $\begin{array}{l}\text { r- } \\
\text { correlation } \\
\text { values }\end{array}$ & $\begin{array}{l}\text { r- } \\
\text { critical }\end{array}$ & p-values & $\begin{array}{l}\text { Level of } \\
\text { significant }\end{array}$ & Decision \\
\hline 1 & $\begin{array}{l}\text { Physics } \\
\text { PSES - TPAS }\end{array}$ & 12 & 0.135 & 0.576 & 0.675 & 0.05 & NS \\
2 & $\begin{array}{l}\text { Chemistry } \\
\text { PSES - TPAS }\end{array}$ & 62 & 0.224 & 0.232 & 0.483 & 0.05 & NS \\
3 & $\begin{array}{l}\text { Biology } \\
\text { PSES - TPAS }\end{array}$ & 55 & 0.407 & 0.250 & 0.189 & 0.05 & NS \\
4 & $\begin{array}{l}\text { Mathematics } \\
\text { PSES - TPAS }\end{array}$ & 12 & 0.357 & 0.576 & 0.255 & 0.05 & NS \\
5 & $\begin{array}{l}\text { Integrated Science } \\
\text { PSES - TPAS }\end{array}$ & 15 & -0.291 & 0.514 & 0.358 & 0.05 & NS \\
\hline
\end{tabular}

$\mathrm{P}>0.05$ in all cases. $\mathrm{R}$ calculated value in all cases $<\mathrm{r}$ critical values.

Table 7: Sample of the pre-service basie science teachers and their subject combination areas of college of education 1

\begin{tabular}{|lllll|}
\hline Subject combination & $\begin{array}{l}\text { No of } \\
\text { teachers }\end{array}$ & pre-service & $\begin{array}{c}\text { science } \\
\text { 50\% } \\
\text { population }\end{array}$ & Sample \\
\hline Integrated Science/Biology & 14 & 7 \\
Biology/Chemistry & 20 & 10 \\
Mathematics/Chemistry & 13 & 7 \\
Chemistry/Computer Science & 7 & 4 \\
Integrated Science/Chemistry & 16 & 8 \\
Computer/Science/Biology & 20 & 10 \\
Total & 90 & 46 \\
\hline
\end{tabular}

Table 8: The sample of the pre-service basic science teachers and their subject combination areas of College of Education II

\begin{tabular}{|c|c|c|}
\hline Subject combination & $\begin{array}{l}\text { No of pre-service } \\
\text { teachers }\end{array}$ & $\begin{array}{l}50 \% \text { Sample of } \\
\text { population }\end{array}$ \\
\hline Integrated & 9 & 5 \\
\hline science/Chemistry & 57 & 29 \\
\hline Biology/Chemistry & 12 & 6 \\
\hline Physics/ Chemistry & 8 & 4 \\
\hline Physics/Computer Science & 23 & 12 \\
\hline Mathematics/Physics & 9 & 5 \\
\hline Biology/Integrated science & 10 & 5 \\
\hline $\begin{array}{l}\text { Mathematic/ Chemistry } \\
\text { Total }\end{array}$ & 125 & 66 \\
\hline
\end{tabular}


Stella Ejovwoke Ewesor and Andrew O. Urevbu: Relationship between perceived selfefficacy and teaching practice performance among pre-service basic science teachers in colleges of education, Delta State, Nigeria

\section{Discussion}

The results of Table 1 shows that the means and standard deviation of the PSES and TPAS groups are 75.77 and 18.79; 62.53 and 6.43 respectively and the correlation of $r$ shows that hypothesis one is accepted because $r$ value of 0.049 shows that there was a positive correlation between the pre-service basic science perceived self-efficacy scores and their teaching practice assessment. Table 5 shows the summary table of paired samples Biavariate correlation of PSES and TPA of students in COE I and COE II. The table also shows that correlation coefficient $r$ value for COE1, group is -0.120 which is higher than the value for COE2 group (-0.024). Thus it shows there is a difference of 0,096 in the correlation coefficient of COE1 and COE2 in teaching practice. It is also seen that the means of the PSES and TPAS scores of COE1, group are higher (83.63 and 6483) than those of COE II (70.28 and 6.092) meaning that hypothesis 2 is accepted because, No significant relationship found between COE I and COE II pre-service basic science teacher perceived selfefficacy scores and their performance in teaching practice scores.

Table 6 shows Pearson paired Sample Bivariate Correlation Analysis for different subject groups perceived selfefficacy and teaching practice assessment. The Pearson correlation $r$ gave all positive values except in the integrated science and biology groups with a negative value of 0.291 and -0.407 . The positive values of $r$ in the other groups tells the relationship between the students perceived self efficacy and their teaching practice scores were increasing or decreasing together. The negative value of $r$ in the integrated science and biology groups tells while one variable increases e.g. self efficacy, the other will decrease e.g. TPAS. Results also show that the Physics group had the lowest $\mathrm{r}$ value $(0.135)$ which is a weak positive correlation, while the Biology group had the highest $r$ value of 0.407 . It means that hypothesis 3 is accepted because no relationship between subject combinations found of pre-service science teachers perceived self-efficacy score and their performance in teaching practice assessment scores.

Results of this study agreed with the study of Egger (2006), he found that there is no relationship between the teaching experience and the efficacy beliefs of the teachers, this agrees with the findings of hypothesis 1 , since there is no significant relationship between the perceived self-efficacy of pre- service basic science teachers and their performance in teaching practice. Azar (2010) found that the self-efficacy and outcome expectancy scores of secondary science in-service and pre-service teachers were equal. That outcome expectancy scores of secondary science in-service and pre- service teachers do not differ according to the type of school graduated from. This agrees with the findings of the hypothesis two, since there was no significant difference between COE1 and COE2 of perceived self-efficacy and their performance in teaching practice.

Azar (2010) found that personal self-efficacy scores of secondary schools science in-service and pre-service teachers differ according to subject major. The highest level of self-efficacy belonged to those majoring in Biology however, there is no difference between in-service and pre-service teachers in terms of outcome expectancy scores. This agrees with the findings of hypothesis three, since there is no significant difference between subjects combination of pre-service basic science teachers' perceived self - efficacy and their performance in teaching practice. In agreement with others researchers (Yulmaz \& Cavas, 2008; SavasciAcikalin, 2013; Nneji, 2013), the findings of this study can help to develop and improve teacher education programs and pre-service teaching practices. Teacher 
Stella Ejovwoke Ewesor and Andrew O. Urevbu: Relationship between perceived selfefficacy and teaching practice performance among pre-service basic science teachers in colleges of education, Delta State, Nigeria

education programmes must be designed to bridge the gap between theory and practice and to better prepare these teachers. Also, pre-service science teachers should involve in constructivist method of teaching in order to enhance their science teaching efficacy beliefs (Awofala, 2011). Therefore, teacher educators have a great role in helping preservice teachers increase their self-efficacy beliefs about science teaching.

\section{Conclusion}

The present research findings have something with what former researchers did in the past. A positive correlation exist between the pre-service basic science teachers perceived self-efficacy scores and their teaching practice assessment, that is why as one group increases or decreases, the other also increases or decreases. This shows that the $r$ value is very low and closer to zero than to 1 , and it shows the relationship has very low strength. This is in line with Egger (2006), he said that there was no relationship between the teaching experience and the efficacy beliefs of the teachers, for there was no relationship between teaching practice performance and perceived self-efficacy of pre-service Basic science teachers. Since there was no relationship between COE1 and COE2 perceived self - efficacy of preservice science teachers and their teaching practice performance. There was no relationship between subject combinations of perceived self - efficacy of pre-service science teachers and their teaching practice performance. Conclusively, the study then reviews that pre-service basic science teachers have high self-efficacy and teaching practice performance respectively.

The following recommendations are made based on the findings and conclusion arising from the study.

1. There should be reform in preservice teacher education programmes in all our teacher training institutions which should aim at strengthening both content and pedagogical knowledge of pre-service science teachers.

2. Teacher educators must model good pedagogy linked science content and foster a supportive environment where pre-service teachers can explore and practice their new skills.

3. Teacher trainer selected for the supervision of pre-service science teacher during teaching practice should be certificated educationists only.

4. Conferences, seminars and workshops should be organized to re-inform and train personals on evaluation techniques.

\section{References}

Appleton, K (2003). How do beginning primary school teachers cope with science? Toward an understanding of science teaching practice. Research in Science Education, 33, $1-25$.

Aurah, M. and Mc Connell, T.J. (2014). Comparative study on pre-service science teachers' self-efficacy beliefs of teaching in Kenya and the United States of America; USA. American Journal of Educational Research, 2(4), 233239. Retrieved from http://pubs. sciepub.com/ education/2/4/9. doi: 10.12691/educa tion-2-4-9.

Awofala, A.O.A and Sopekan, O.S. (2013). Recent curriculum reforms in primary and secondary schools in Nigeria in the new millennium, Journal of Education and Practice. 4 (5), 98-107

Azar, A. (2010). In-service and pre-service secondary science teachers' selfefficacy beliefs about science teaching. Educational Research and Reviews, 5(4), 175-188. 
Stella Ejovwoke Ewesor and Andrew O. Urevbu: Relationship between perceived selfefficacy and teaching practice performance among pre-service basic science teachers in colleges of education, Delta State, Nigeria

Bandura, A. (1993). Perceived self efficacy in cognitive development and functioni $\mathrm{n}$ g. Educational Psychologist, 28(2),11 7-148.

Brand, B.R and Wilkins, J.L.M (2007) using self-efficacy as a construct for evaluating science and mathematics methods courses. Journal of Science Teacher Education 18(2), 297-317

Dorman, J.P. and Odgers, B.M (2004) Assessment of science teacher efficacy of pre-service teachers in an Australian university. Journal of Science Teacher Education, 15(4), 313-331.

Egger K.J (2006). An exploration of the relationships among teacher efficacy, collective teacher efficacy and teacher demographic characteristics in conservation Christian schools. Unpublished Doctorate Thesis, University of North Texas.

Enochs, L. G. and Riggs, I. M. (1990). Further development of an elementary science teaching efficacy belief instrument: A preservice elementary scale. School Science \& Mathematics, 90, 694706.

Ewesor, S.E. (2019). Relationship between perceived self-efficacy and teaching practice performance among pre-service basic science teachers in colleges of education, Delta State. Unpublished MPhil. Dissertation, Department of Curriculum and Instructional
Technology, Faculty of Education, University of Benin, Benin City.

Hechter, R.P. (2011). Changes in preservice primary teachers' personal science teaching efficacy and science teaching outcome expectancies, The influence of context. Journal of Science Teacher Education, 22(2), 187202.

Mulholland, J, and Wallace, J. (2000). Beginning elementary science teaching: Entryways to different worlds. Research in Science Education 30, 151-171.

Nneji, L.M. (2013). Examining the effect of teaching practice on pre service basic science teachers' science teaching efficacy beliefs. Indian Streams Research Journal, 3(5), 19.

Savasci-Acikalin, F.(2014). A study of pre-service teachers' science teaching efficacy beliefs during the elementary science laboratory course. Procedia - Social and Behavioral Sciences 141, 221-226. Retrieved from file://C:/Users/UL/AppData/Local/ Temp/A_Study_of_Pre-service _Teachers_Science_Teaching_.pdf. doi: 10.1016/j.sbspro.2014.05.038.

Yilmaz, H. and Cavas, P. H. (2008). The effect of the teaching practice on pre-service elementary teachers' science teaching efficacy and classroom management beliefs. Eurasia Journal of Maths, Science \& Teacher Education, 4(1), 45-54. 